\title{
First report on the palaeopsychrospheric ostracod genus Nemoceratina (Pariceratina) Gründel and Kozur, 1972 (Ostracoda, Bythocytheridae) from the Quaternary of the Mediterranean basin and description of a new species
}

\author{
Francesco Sciuto
}

\begin{abstract}
The first occurrence of the ostracod genus Nemoceratina (subgenus Pariceratina) Gründel and Kozur, 1972 (Podocopida, Bythocytheridae) in the Quaternary of the Mediterranean area is reported and the paleoenvironmental significance of this palaeopsychrospheric genus is discussed in the context of the geological history of the Tethydean area. A new species Nemoceratina (Pariceratina) barrieri n. sp., is described. The specimens have been discovered in "Cala S. Antonino" along the western slope of the Cape Milazzo Peninsula (Northeastern Sicily) in Gelasian sandy-silty sediments cropping out unconformably on a conglomerate attributed to the Tortonian (Upper Miocene) and formed as a result of the erosion of the underlying metamorphic rocks belonging to the "Calabride Complex". The genus Nemoceratina seems to be widespread in the Middle Triassic sediments of Central Europe where it is considered a palaeopsychrospheric ostracod, i.e. a marker of palaeoclimatic and palaeoecological conditions characteristic of deeper and cold Triassic ocean waters. Monoceratina becomes scarcer in the Cenozoic, but maintains its psychrospheric characteristics. The genus is very rare in the Quaternary, and its discovery in the Pleistocene deep water sediments suggests that it has maintained its ecological requirements through time. The species Nemoceratina (Pariceratina) barrieri n. sp., is considered a residual element of the deep water Tethyan ostracod fauna.
\end{abstract}

Francesco Sciuto. Palaeoecological Research Group, Department of Biological, Geological and Environmental Science, Catania University, Corso Italia, 55, Catania 95129, Italy. fsciuto@unict.it

Keywords: marine ostracods; Bythocytheridae; new species; Gelasian Stage; bathyal

PE Article Number: 17.3.32A

Copyright: Palaeontological Association October 2014

Submission: 23 August 2013. Acceptance: 31 August 2014

http://zoobank.org/E267ED8A-F9D5-441E-B4D1-578F08E2AF4F

Sciuto, Francesco. 2014. First report on the palaeopsychrospheric ostracod genus Nemoceratina (Pariceratina) Gründel and Kozur, 1972 (Ostracoda, Bythocytheridae) from the Quaternary of the Mediterranean basin and description of a new species. Palaeontologia Electronica Vol. 17, Issue 3;32A; 10p;

palaeo-electronica.org/content/2014/888-new-quaternary-ostrocod 


\section{INTRODUCTION}

The ostracods belonging to the genus Nemoceratina (subgenus Pariceratina) Gründel and Kozur, 1972 are extremely rare and poorly known, especially in the post-Mesozoic. Few reports exist for the Cenozoic (Whatley and Boomer, 1995), while in the Recent reports are very rare (Boomer and Whatley, 1995).

The type species of the genus Nemoceratina Gründel and Kozur, 1972, Triceratina triassica Kozur, 1970, is reported for the first time in the Middle Triassic of Hungary, while the type species of the subgenus Pariceratina Gründel and Kozur,1972, Cytheropteron cuspidatum var. tricuspidata (Jones and Hinde, 1890), is reported from the Cretaceous of England. The genus Nemoceratina appears for the first time in the Middle Triassic (Kozur, 1970) while according to Schornikov (1988, 1990) Pariceratina appears in the Cretaceous.

In the Mesozoic, species belonging to this genus or subgenus are: Pariceratina liebaui Dingle, 1984 reported from the Albian of the Falkland Plateau; Pariceratina trispinosa (Neale, 1975) from the Santonian of Western Australia (Neale, 1975; Guzel, 2012); Pariceratina hirsuta Dingle, 1981 from the Maastrichtian of South Africa and Western Australia; Nemoceratina tewarii Jain, 1975 from the Cretaceous of Rajasthan (India) (Andreu et al., 2008); Pariceratina ubiquita Boomer, 1994 from the Cretaceous of Central Pacific (Boomer, 1999); Pariceratina tricuspidata (Jones and Hinde, 1890) from the Campanian of North Atlantic basin (Neale, 1977), and specimens in open nomenclature belonging to the genus Pariceratina are reported from Mesozoic submarine cores in South Atlantic Ocean across the Rio Grande Rise and Walvis Ridge (Benson et al., 1985).

Fossil records from the Mesozoic of Europe include: Nemoceratina (Pariceratina) urlichsi Schudack and Schudack, 2000, from the Upper Jurassic of south Germany; Pariceratina tricuspidata (Jones and Hinde, 1890) from the Turonian of south-east England (Slipper, 1997); Nemoceratina (Pariceratina) tricuspidata (Jones and Hinde, 1890) from the Upper Cretaceous and basal Cenomanian of east Anglia (Wilkinson, 1988; Pyne, 2001); from early Campanian to middle-late Maastrichtian of Belgium (Bless et al., 1990); Nemoceratina (Pariceratina) sp. from the Bathonian of the Paris Basin (Dépêche, 1985); Nemoceratina (Pariceratina) bicuspidata Gründel, 1967 from the Albian of Germany (Damotte et al., 1981).

In the Cenozoic Pariceratina sp.1 are reported from Lower Miocene submarine cores in the West-

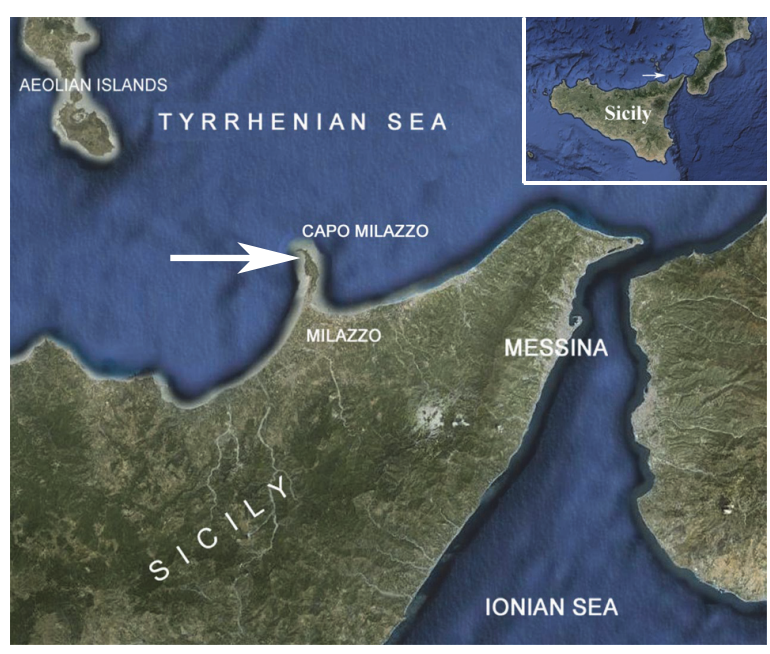

FIGURE 1. Geographical location of the Capo Milazzo Peninsula.

ern Pacific (Boomer and Whatley, 1995); Pariceratina ubiquita Boomer, 1994 from the Oligocene of Central Pacific (Boomer, 1999); Pariceratina sp.1 and Pariceratina sp. 2 from the Paleocene and Eocene of the Atlantic Ocean (Guernet and Bellier, 2000) and the genus Pariceratina from upper Paleocene to Middle Eocene in North Atlantic Ocean and Early Eocene to Middle Miocene in the Pacific Ocean (Coles et al.,1990). In the Recent the genus is only known from sediments of the Central Pacific Ocean (Boomer and Whatley, 1995).

There are no listed reports of this genus in the Mediterranean area. The first occurrence of Nemoceratina (Pariceratina) Gründel and Kozur, 1972 is reported here for specimens found in bathyal sediments cropping out in "Cala S. Antonino" (Cape Milazzo, NE Sicily) deposited during the Gelasian Stage, and a new fossil species belonging to this genus and subgenus is erected.

\section{MATERIALS AND METHODS}

Discontinuous lenses of yellowish fine sands and silts crop out along the steep slopes of the Cape Milazzo Peninsula (NE Sicily) (Figure 1). The sandy-silty sedimentary succession rests unconformably on shallow-water Miocene limestones, directly on the metamorphic basement of the Calabride Complex, or on a conglomerate formed as a result of the fragmentation of the underlying metamorphic rocks. The sedimentary succession is truncated by the Tyrrhenian erosive surface, with a thin layer of polygenic conglomerates deposited on 


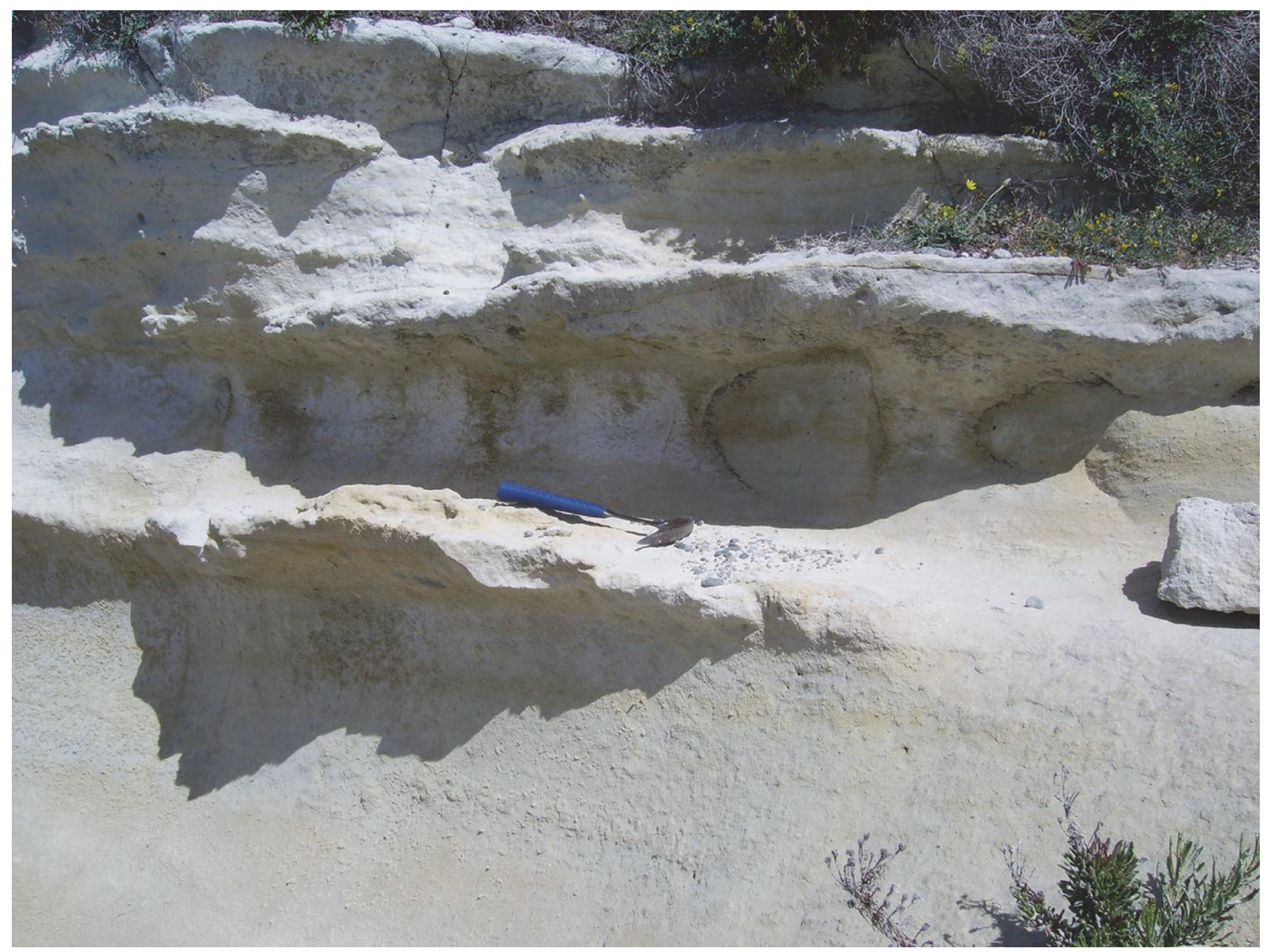

FIGURE 2. The yellow Gelasian calcareous sandy-silts resting unconformably on the Tortonian conglomerate.

it. The sedimentary sequence is terminated by Aeolian volcanic ashes.

Sandy-silty sediments were deposited during the Gelasian Stage although locally reaching the Sicilian stage (Violanti, 1988; Fois, 1990a, 1990b; Sciuto, 2003, 2005, 2009, 2014) in epibathyal environments as suggested by the presence of brachiopods (Gaetani and Saccà, 1984), bryozoans (Rosso, 2002), foraminifers (Violanti, 1988), and ostracod associations (Sciuto, 2003, 2005, 2009, 2014).

At Cala S. Antonino the Gelasian layers (Figure 2) crops out unconformably on a conglomerate (Figure 3) attributed to the Tortonian (Fois, 1990a, 1990b) and formed as a result of the fragmentation of the underlying metamorphic rocks of the "Calabride Complex". In the Gelasian sediments, just on the unconformity with the underlying conglomerates, some specimens belonging to Bythocytheridae Sars, 1866 were found; they do not appear to be related to any known species.

Two samples were collected from the same stratigraphic level. Ostracods were studied from
$300 \mathrm{cc}$ samples. Sediments were routinely washed and ostracod specimens picked out from the 63$500 \mu \mathrm{m}$ fraction. The ostracod specimens were examined, photographed, and measured under LMU Tescan Vega II SEM. The material is housed in the Palaeontological Museum of the University of Catania. The repository number of the Holotype and the Paratypes are given in the systematic descriptions.

\section{RESULTS}

\section{Systematic description}

Class OSTRACODA Latreille,1806

Order PODOCOPIDA Sars, 1866

Family BYTHOCYTHERIDAE Sars, 1866

Genus NEMOCERATINA Gründel and Kozur, 1972

Subgenus PARICERATINA Gründel and Kozur, 1972

Type species. Nemoceratina (Pariceratina) tricuspidata (Jones and Hinde, 1890) 


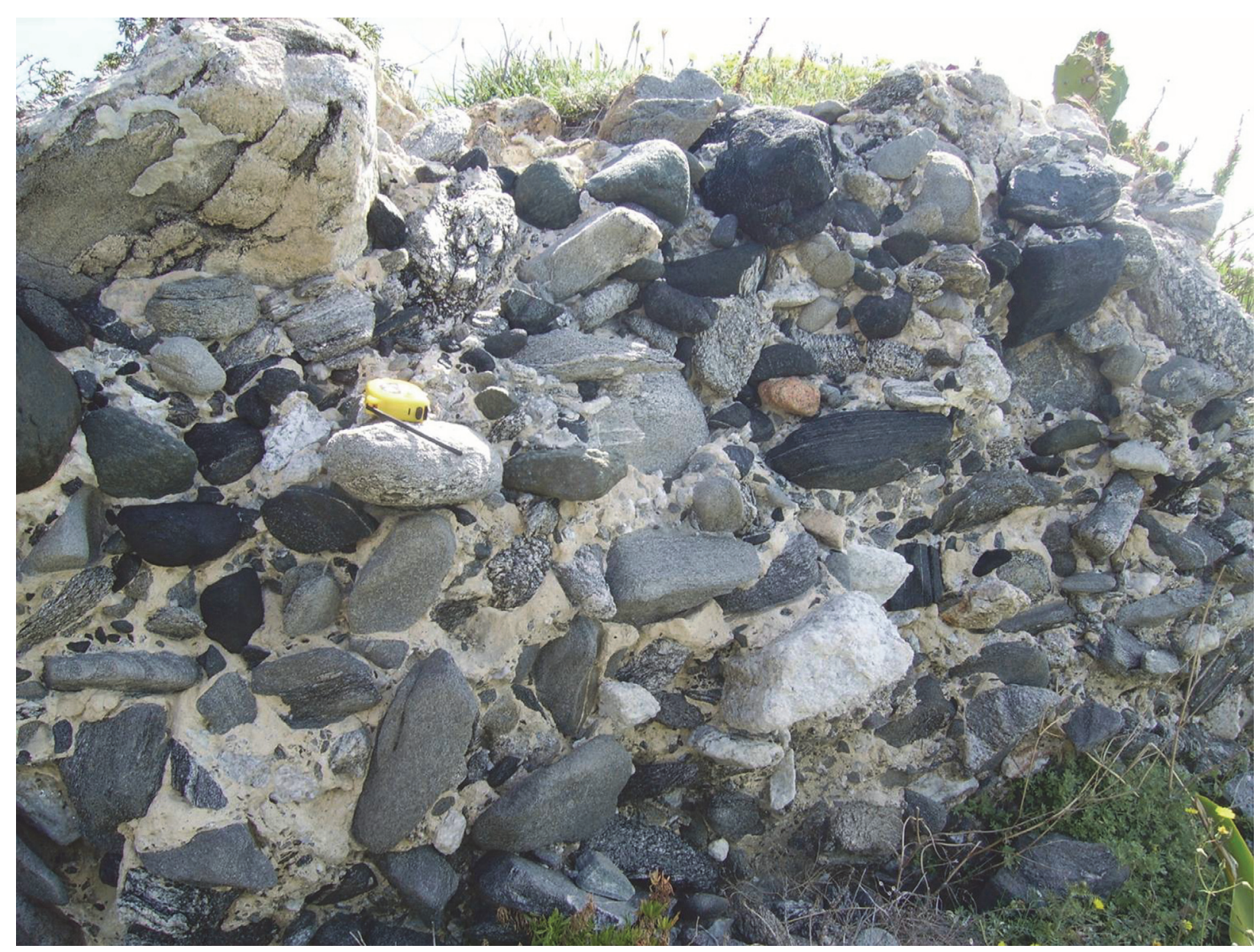

FIGURE 3. The Tortonian conglomerate formed as a result of the fragmentation of the underlying metamorphic rocks of the "Calabride Complex."

Nemoceratina (Pariceratina) barrieri n. sp.

Figure 4.1-12

\section{zoobank.org/6F805A16-3474-4D9B-9FFF-6156C9E35E0F}

Holotype. The right valve, figured in Figure 4.4, PMC. O 9H 30/7/2013 ( $\mathrm{L}=700 \mu \mathrm{m}, \mathrm{H}=324 \mu \mathrm{m})$.

Paratypes. Two left valves and three right valves figured in Figure 4.1-3, 4.5-12. Figure 4.1, PMC. O 30P 30/7/2013 ( $\mathrm{L}=688 \mu \mathrm{m}, \mathrm{H}=320 \mu \mathrm{m})$; Figure 4.2, PMC. O 31P 30/7/2013 (L=680 $\mu \mathrm{m}, \mathrm{H}=320$ $\mu \mathrm{m})$; Figure 4.3, PMC. O 32P 30/7/2013 (L = 585 $\mu \mathrm{m}, \mathrm{H}=280 \mu \mathrm{m})$; Figure 4.5, PMC. O 30P 30/7I $2013(\mathrm{~L}=640 \mu \mathrm{m}, \mathrm{H}=301 \mu \mathrm{m})$; Figure 4.6, PMC. O 32P 30/7/2013 ( $\mathrm{L}=585 \mu \mathrm{m}, \mathrm{H}=271 \mu \mathrm{m})$; Figure 4.7, PMC. O 33P 30/7/2013 ( $\mathrm{L}=680 \mu \mathrm{m}, \mathrm{H}=300$ $\mu \mathrm{m})$, Figure 4.11, PMC. O 34P 30/7/2013 (L = 645 $\mu \mathrm{m}, \mathrm{H}=299 \mu \mathrm{m})$.

Type locality. Cala S. Antonino along the western side of the Cape Milazzo Peninsula (Tav. Milazzo, F.253 IV SO, 38 $15^{\prime} 40^{\prime \prime} \mathrm{N}, 15^{\circ} 14^{\prime} 12^{\prime \prime} \mathrm{E}$ ) in the yellow sandy silts of Gelasian Stage cropping out uncon- formably on a conglomerate consisting of metamorphic elements of the "Calabride Complex".

Stratigraphic range. Gelasian Stage.

Derivatio nominis. The species is named after Prof. Pascal Barrier, Geologist, Dean at the Institut Polytecnique LaSalle-Beauvais (France), for his scientific engagement in Sicily.

Material. 6 valves.

Other material. A single left valve of a juvenile from the same locality.

Diagnosis. Nemoceratina (Pariceratina) barrieri $\mathrm{n}$. $\mathrm{sp}$. is characterized by subrectangular elongate valves with three aligned lateral spines. Valve surface tuberculate, spinous, and partially reticulate.

Description. Carapace elongated medium-sized subrectangular in lateral view (Figure 4.1-3, 4.7). Anterior margin regularly arched with numerous fine spines and denticles. Anterior cardinal angle strongly developed, posterior cardinal angle weaker. Dorsal margin long and straight, with numerous stubby composite denticles anteriorly, 


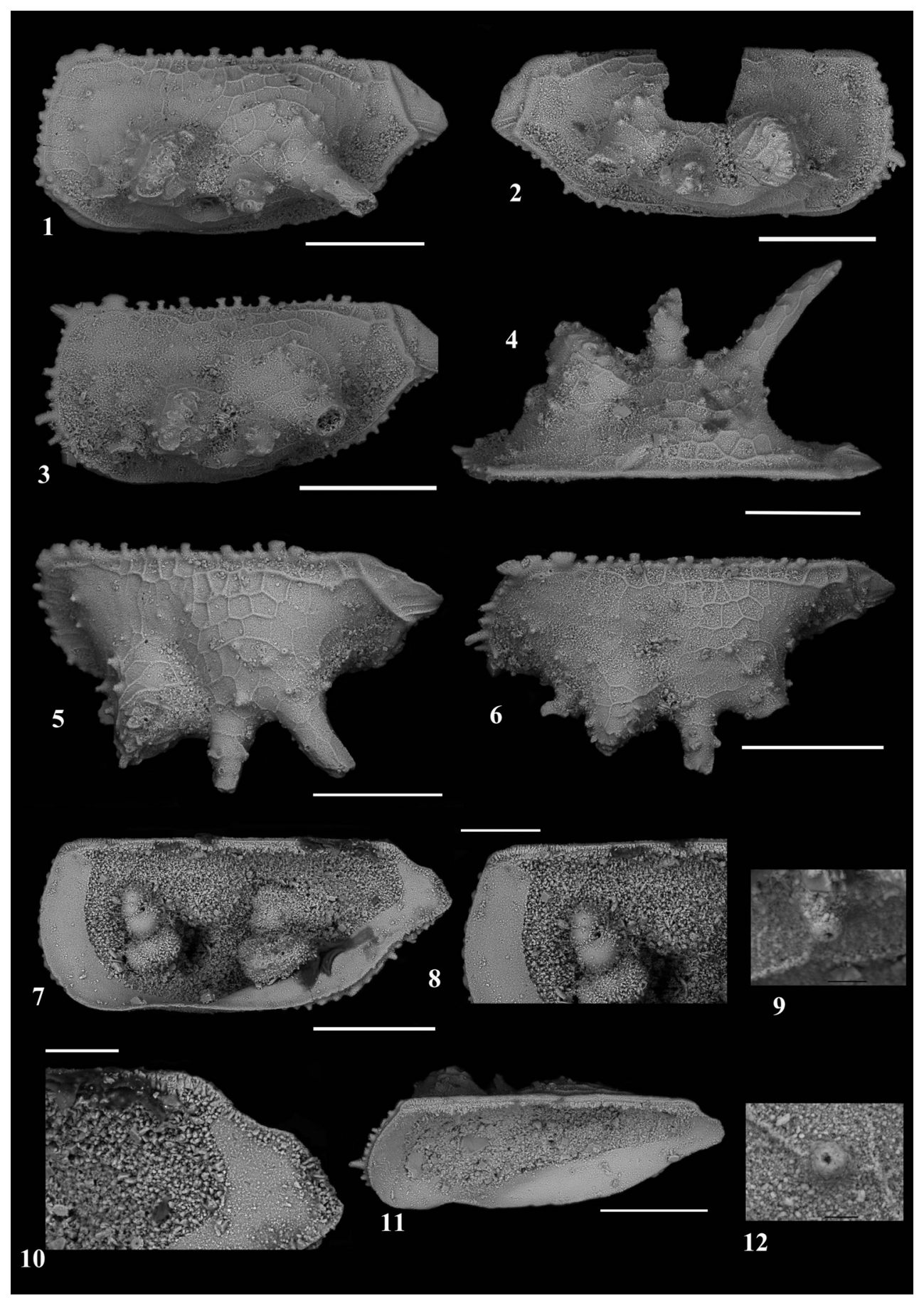

FIGURE 4. Nemoceratina (Pariceratina) barrieri n. sp. 4.1, Left valve, Paratype PMC. O 30P 30/7/2013, external lateral view (scale bar $200 \mu \mathrm{m}$ ). 4.2, Right valve, Paratype PMC. O 31P 30/7/2013, external lateral view (scale bar 200 $\mu \mathrm{m})$. 4.3, Left valve, Paratype PMC. O 32P 30/7/2013, external lateral view (scale bar $200 \mu \mathrm{m})$. 4.4, Right valve, Holotype PMC. O 9H 30/7/2013, external dorsal view (scale bar $200 \mu \mathrm{m}$ ). 4.5, Left valves, Paratypes PMC. O 30P 30/7/ 2013, external dorsal view partially slanting (scale bar $200 \mu \mathrm{m}$ ). 4.6, Left valves, Paratypes PMC. O 32P 30/7/2013, external dorsal view partially slanting (scale bar $200 \mu \mathrm{m}$ ). 4.7, Right valve, Paratype PMC. O 33P 30/7/2013, internal lateral view (scale bar $200 \mu \mathrm{m}$ ). 4.8, Right valve, Paratype Paratype PMC. O 33P 30/7/2013, internal lateral view, detail of the anterior marginal area (scale bar $100 \mu \mathrm{m}$ ). 4.9, External lateral view, Paratypes PMC. O 32P 30/7/2013, normal pores (scale bar $10 \mu \mathrm{m}$ ). 4.10, Right valve, Paratype Paratype PMC. O 33P 30/7/2013, internal lateral view, detail of the posterior marginal area (scale bar $50 \mu \mathrm{m}$ ). 4.11, Right valve, Paratype PMC. O 34P 30/7/2013, internal lateral view, partially slanting (scale bar $200 \mu \mathrm{m}$ ). 4.12, External lateral view, Paratypes PMC. O 32P 30/7/2013, normal pores (scale bar $10 \mu \mathrm{m})$. 
spines central-posteriorly. The dorsal margin passes into the caudal process, in the posterior area, through an obtuse angle in subdorsal position. Caudal process short, slightly acute and well marked. Ventral margin weakly convex, smooth anteriorly, spinous posteriorly, regularly and steeply curved posteriorly towards the caudal process, to which joins with an inflection.

The anterior and posterior marginal area is wide and flattened. Central part of the carapace is inflated with three prominent elements aligned in antero-posterior direction. The first anteriorly is a large and acute spine like a tubercle with a very large base; the second, centrally, is an acute spine; the third in postero-central area is a longer spine, acute and inclined ventrally.

Outer surface ornamented with a weak and irregular polygonal reticulum, which also affects the surfaces of tubercles and the spines. This ornamentation dissolves in antero-dorsal and mid-posterior area. Caudal process ornamented with a chevron-shaped ridge running into the ventral margin (Figure 4.1-3). Marginal ridge well marked and developed along the valve outline except for dorsal area (Figure 4.1-3). A broad oblique median sulcus is present between the first and the second anterior spine. Eye tubercles are absent.

Normal pore-canals few and simple, some of which on tubercles (Figure 4.9, 4.12). Inner lamella: anteriorly and postero-ventrally wide (Figure 4.7-8, 4.10). Anterior and posterior vestibula are present. Marginal pore canals are not visible, and there is no evidence of sexual dimorphism. Hinge is simple and straight and consists of a groove parallel to the dorsal margin in the RV (Figure 4.7-8, 4.10-11), LV complementary. Muscle scars are not visible.

Remarks. The subgenus Pariceratina Gründel and Kozur, 1972, according to the authors, should be characterized by three lateral spines of approximately equal strength. However, the type species Cytheropteron cuspidatum var. tricuspidata (Jones and Hinde, 1890) has spines of variable strength, of which the longest is located in the postero-central area. Probably because of the different strength of the spines, the subgenus Pariceratina was amended and raised to the generic level by Dingle (1981) when he described Pariceratina hirsuta n. sp. from the Maastrichtian of South Africa. The features of $P$. hirsuta Dingle, 1981 seem to be a synthesis of those shown by the genus Nemoceratina Gründel and Kozur, 1972 and the subgenus Pariceratina Gründel and Kozur, 1972.
Weaver (1982) highlights the diagnosis of both genus and subgenus. The species $P$. tricuspidata (?) is assigned to the genus Nemoceratina, because of the general shape of the shell and the three prominent lateral spines, and to the subgenus Pariceratina using the surface morphology partially characterized by spines, tubercles, and a geometric reticulation, as well as by a very simple hinge.

Boomer (1994) amended the diagnosis of the subgenus Pariceratina and described $P$. ubiquita again promoting the subgenus to the generic level. Following Weaver (1982), the species described here has been assigned to the genus Nemoceratina using the general shape of the shell and the three prominent lateral spines; the species has subsequently been referred to the subgenus using the surface morphology and the type of the hinge.

Nemoceratina (Pariceratina) barrieri n. sp. shows some similarities with the other species of the genus and subgenus mainly because of the general shape of the carapace and the three strong lateral spines. However, the species is distinguished from the type species of the subgenus, Nemoceratina (Pariceratina) tricuspidata (Jones and Hinde, 1890) essentially because the new species is longer.

Indeed, Nemoceratina (Pariceratina) tricuspidata (Jones and Hinde, 1890) described by Weaver (1982) from the Cenomanian of south England, by Slipper (1997) from the Turonian of south-east England, and by Pyne (2001) from the Upper Cretaceous of eastern England, appears smaller. Besides, the new species shows a different distribution of the tubercles on the valves surface, as well as a different position of the three spines on the carapace, i.e. in a more central position than in the type species.

Compared to the species here described, Pariceratina trispinosa (Neale, 1975), shows a much more irregular valve surface, an anterior margin not regularly curved, and a different position and shape of the caudal process.

Pariceratina sp. 1 and Pariceratina sp. 2 found in a submarine core off Florida by Guernet and Bellier (2000) show very different features when compared to the new species: four large spines in central-ventral area of the carapace and a single spine in antero-dorsal margin (Pariceratina sp. 1), a reticulation that completely covers the valve and a different distribution of spines and tubercles on the carapace (Pariceratina sp. 2).

Pariceratina sp. 1 found by Boomer and Whatley (1995) in submarine cores of the western 
Pacific is distinguished from N. (Pariceratina) barrieri $\mathrm{n}$. sp. mainly because the polygonal reticulum entirely covers the carapace.

Nemoceratina (Pariceratina) barrieri n. sp. is quite similar to Pariceratina liebaui (Dingle, 1984), because of the spinous outline anteriorly and postero-ventrally, the marginal ridge and the ornamentation of the caudal process; it is however distinguished by the position and dimensions of the three spines.

\section{DISCUSSION}

The data relating to the findings of the genus Nemoceratina shows a wide stratigraphical distribution from the Trias to the Recent. In the Mesozoic, this genus shows a wide palaeogeographical distribution that includes the South Tethyan Ostracod Province (sensu Andreu et al., 2008) (Neale, 1975; Dingle, 1984; Benson et al., 1985; Andreu et al., 2008; Guzel, 2012) and the Central European basins (Damotte et al., 1981; Dépêche, 1985; Wilkinson, 1988; Bless et al., 1990; Slipper, 1997; Schudack and Schudack, 2000; Pyne, 2001) in which at least two brief Tethyan faunistic incursions occurred during the early Campanian and the middle late Maastrichtian (Bless et al., 1990). Therefore the discovery of Nemoceratina in the Mediterranean Pleistocene deep water deposits suggests that they are a residual element of the Tethyan ostracod fauna.

Taking into account the data currently published, Nemoceratina specimens are almost always referred to deep water palaeoenvironments, both in the Mesozoic and in the Cenozoic (Dingle, 1981; 1984; Boomer and Whatley, 1995; Boomer, 1999; Guernet and Bellier, 2000, inter alias). As a consequence, the ecological requirements of the genus Nemoceratina do not seem to have changed through time, apparently always remaining a deep water genus.

The new species here described has been found in the Gelasian, associated with an ostracod fauna strongly dominated by few species, and particularly by Agrenocythere pliocenica (Seguenza, 1880), Costa tricostata pliocenica Ruggieri, 1992, Pseudocythere caudata Sars, 1866, Monoceratina mediterranea Sissingh, 1971, Cytheropteron spp., followed in order of abundance by Paradoxostoma tenuissimum (Norman, 1869), Xestoleberis cf. $X$. pasta Abate et al., 1994, Bythocythere solisdeus Sciuto, 2012, Bairdoppilata profunda Aiello et al., 2000, Bythocypris obtusata (Sars, 1866), Henryhowella ex $H$. profunda group Bonaduce et al., 1999, Eucythere curta Ruggieri, 1975, Propontocy- pris sp. Bairdoppilata conformis (Terquem, 1878), Trachyleberis hystrix (Reuss, 1849), Pedicythere phryne Bonaduce et. al., 1976, Sclerochilus contortus (Norman, 1862), Paracytherois spp. (Sciuto 2003, 2005, 2009, 2014). The composition and assemblage structure of this type has been interpreted as indicative of bathyal environments (Benson, 1975; Dingle and Lord, 1990). Considering the bathymetric distribution of the most common species still living (i.e., B. obtusata and B. conformis) and the paleoenvironmental deductions on extinct species, the ostracofauna associated to the new species refers to, as an approximation, a palaeobiotope located at a depth greater than 600 meters (Sciuto, 2005). The presence of Agrenocythere pliocenica is particularly significant because, according to Benson (1972a, 1972b), it indicates psychrospheric oceanic conditions. Therefore Nemoceratina (Pariceratina) barrieri n. sp. can be considered as a marker of deep water palaeoenvironments characterized by low temperatures.

According to Kozur (1991) and Aihua (2008) the genus Nemoceratina in the Trias was included in palaeopsychrospheric ostracod assemblage, so it would be a marker of palaeoclimatic and palaeoecological conditions characteristic of the deeper Triassic ocean waters.

Data on Triassic palaeopsychrosphere are scarce and incomplete, but further discoveries of the genus Nemoceratina in post Eocene sediments (beginning of the modern psychrosphere according to Benson, 1975, 1984 and McKenzie, 1982) suggests that the genus would keep psychrospheric characteristic through the time. The stability of the chemical-physical characteristics of the deep water palaeoenvironment, and especially of the psychrosphere, would permit the survival of the genus through time.

\section{ACKNOWLEDGEMENTS}

The author is grateful to the reviewers and to the editors for the detailed suggestions and corrections to the manuscript. Thanks are also due to Mr. A. Viola (University of Catania) for collaboration and SEM photos. Catania Palaeoecological Research Group contribution n. 391.

\section{REFERENCES}

Abate, S., Barra, D., and Bonaduce, G. 1994. The Deepwater Xestoleberidinae Sars, 1928 (Crustacea: Ostracoda) in the Pliocene-early Pleistocene of the M. San Nicola section (Gela, Sicily). Revista Española de Micropaleontologia, 26:43-47. 
Aiello, G., Barra, D., and Bonaduce, G. 2000. Systematics and biostratigraphy of the ostracoda of the PlioPleistocene Monte S. Nicola section (Gela, Sicily). Bollettino della Società Paleontologica Italiana, 39:83-112.

Aihua, Y. 2008. Faune d'Ostracodes (Crustacea) d'eau profonde du Permien Terminal de Chine du Sud. Unpublished Thesis. Université Pierre et Marie Curie, Ecole Doctorale Géosciences et Ressources Naturelles, Université de Géosciences de Wuhan. tel.archives-ouvertes.fr/docs/00/81/27/82/PDF/THESE_-_YUAN_Aihua_Adobe_6.0_.pdf

Andreu, B., Colin, J.-P., and Singh, J. 2008. Cretaceous (Albian to Coniacian) ostracodes from the subsurface of the Jaisalmer Basin, Rajasthan, India. Micropaleontology, 53:345-370.

Benson, R.H. 1972a. Ostracodes as Indicators of Threshold Depth in the Mediterranean during the Pliocene, p. 63-73. In Stanley, D.J. (ed.), The Mediterranean Sea: a natural sedimentation laboratory. Stroudsburg, PA.

Benson, R.H. 1972b. The Bradleya problem, with descriptions of two new psychrospheric ostracode genera, Agrenocythere and Poseidonamicus (Ostracoda: Crustacea). Smithsonian Contribution to Paleobiology, 12:1-138.

Benson, R.H. 1975. The origin of the psychrosphere as recorded in changes of deep-sea ostracodes assemblages. Lethaia, 8:69-83.

Benson, R.H. 1984. Estimating greater paleodepths with ostracodes, especially in past thermospheric oceans. Palaeogeography, Palaeoclimatology, Palaeoecology, 48:107-141.

Benson, R.H., Chapman, R.E., and Deck, L.T. 1985. Evidence from the Ostracoda of mayor events in the South Atlantic and World-wide over the past 80 million years, p. 325-350. In Hsu, K.J. and Weisser, H.J. (eds.), South Atlantic Paleoceanography. Cambridge University Press, Cambridge.

Bless, M.J.M., Felder, P.J., and Jagt, J.W.M. 1990. Repeated tethyan influence in the Early Campanian to Middle Late Maastrichtian successions of Folx-lesCaves and Orp-le-Petit (Eastern Brabant Massif, Belgium). Annales de la Société Géologique de Belgique, 113:179-197.

Bonaduce, G., Barra, D., and Aiello, G. 1999. The genus Henryhowella Puri, 1957 (Crustacea, Ostracoda) in the Atlantic and Mediterranean from Miocene to Recent. Bollettino della Società Paleontologica Italiana, 38:59-72.

Bonaduce, G., Ciampo, G., and Masoli, M. 1975. Distribution of Ostracoda in the Adriatic Sea. Pubblicazioni della Stazione Zoologica di Napoli, 40 (Suppl.):1-304.

Boomer, I. 1994. On Pariceratina ubiquita Boomer sp. nov. Stereo-Atlas of Ostracod Shells, 21:79-86.

Boomer, I. 1999. Late Cretaceous and Cenozoic bathyal Ostracoda from the Central Pacific (DSDP Site 463). Marine Micropaleontology, 37:131-147.
Boomer, I. and Whatley, R. 1995. Cenozoic ostracoda from guyots in the Western Pacific: Holes 865B and 866B (Leg 143). Proceedings of the Ocean Drilling Program, Scientific Results, 143:75-86.

Coles, G., Ayress, M., and Whatley, R. 1990. A comparison of North Atlantic and Pacific Cenozoic deep sea Ostracoda, p. 287-306. In Watley, R. and Maybury, C. (eds.), Ostracoda and Global events. Chapman and Hall, London.

Damotte, R., Babinot, J.F., and Colin, J.P. 1981. Les ostracodes du Crétacé Moyen Européen. Cretaceous Research, 2:287-306.

Dépêche, F. 1985. Lias supérieur, Dogger, Malm, p.119145. In Oertly, H.J. (ed.), Atlas des ostracodes de France. Elf Aquitaine, Pau.

Dingle, R.V. 1981. The Campanian and Maastrichtian Ostracoda of South-East Africa. The Annals of the South African Museum, 85:1-181.

Dingle, R.V. 1984. Mid-Cretaceous Ostracoda from Southern Africa and the Falkland Plateau. The Annals of the South African Museum, 93:97-211.

Dingle, R.V. and Lord, A.R. 1990. Benthic ostracods and deep water-masses in the Atlantic Ocean Palaeogeography, Palaeoclimatology, Palaeoecology, 80:213235.

Fois, E. 1990 a. La successione neogenica di Capo Milazzo (Sicilia nord-orientale). Rivista Italiana di Paleontologia e Stratigrafia, 95:397-440.

Fois, E. 1990 b. Stratigraphy and palaeogeography of the Capo Milazzo area (NE Sicily, Italy): clues to the evolution of the southern margin of the Tyrrhenian basin during the Neogene. Palaeogeography, Palaeoclimatology, Palaeoecology, 78:87-108.

Gaetani, M. and Saccà, D. 1984. Brachiopodi batiali del Pliocene e del Pleistocene di Sicilia e Calabria. Rivista Italiana di Paleontologia e Stratigrafia, 90:407458.

Gründel, J. 1967. Neue Ostracoden aus dem Hauterive und alb Deutschlands. Jarbuch Geologie, 1:629-650.

Gründel, J. and Kozur, H. 1972. Zur Taxonomie der Bythocytheridae und Tricorninidae (Podocopida, Ostracoda). Monatsberichte der Deutschen Akademie der Wissenschaften zu Berlin, 13 (for 1971):907937.

Guernet, C. and Bellier, J.-P. 2000. Blake Nose Palaeocene and Eocene ostracods (Leg ODP 171B) and bathyal environmental evolution off Florida. Revue de Micropaléontologie, 43:249-279.

Guzel, M. 2012. Palaeobiogeographic significance of Jurassic and Cretaceous Western Australian ostracod faunas. Unpublished Postgrad Thesis. Deakin University. dro.deakin.edu.au/eserv/ DU:30048942/guzel-palaeobiogeographic-2012.pdf

Jain, S.P. 1975. Cytheracea (Ostracoda) from the Ariyalur Formation (Upper Cretaceous) of South India. Bulletin of the Indian Geological Association, 8:4170. 
Jones, T.R. and Hinde, G.J.1890. A supplementary monograph of the Cretaceous Entomostracea of England and Ireland. Monograph of the Palaeontographical Society, 43:1-70.

Kozur, H. 1970. Neue Ostracoden-Arten aus dem Obersten Anis des Bakonyhochlandes (Ungarn). Berichte des Naturwissenschaftlich-Medizinischen Vereins in Innsbruck, 58:384-428

Kozur, H. 1991. Permian deep-water ostracods from Sicily (Italy). Part 2: biofacial evaluation and remarks to the Silurian to Triassic paleopsichrospheric ostracods. Geologisch-Paläontologische Mitteilungen Innsbruck, 3:25-38.

Latreille, P.A. 1806. Genera crustaceorum et insectorum. A. Koenig. Parisiis et Argentorati.

McKenzie, K.G. 1982. Palaeozoic-Cenozoic ostracoda of Tethys. Bollettino della Società Paleontologica Italiana, 21:311-326.

Neale, J.W. 1975. The ostracod fauna from the Santonian Chalk (Upper Cretaceous) of Gingin, Western Australia. Palaeontological Association Special Papers in Palaeontology, 16:1-81.

Neale, J.W. 1977. Cretaceous ostracoda of the North Atlantic Basin, p. 345-370. In Swain, F.M. (ed.), Stratigraphic micropaleontology of Atlantic Basin and borderlands.

Norman, A.M. 1861. On species of Ostracoda found in Northumberland and Durham, new to Great Britain. Transaction of the Tyneside naturalist, Cl. 5: 143155.

Norman, A.M. 1869. Shetland final dredging report. Part 2. On the Crustacea, Tunicata, Polyzoa, Echinodermata, Actinozoa, Hydrozoa and Porifera. Report of the British Association for the Advancement of Science, 1868: 247-336; 341-342.

Pyne, R. 2001. The Biostratigraphy, Palaeoecology and Taxonomy of Upper Cretaceous (Coniacian to Lower Maastrichtian) Ostracoda from the Chalk of East Anglia. Unpublished Thesis. University of Wales. hdl.handle.net/2160/7768

Reuss, A.E. 1849. Die fossilen Entomostraceen des österreichischen Tertiarbeckens. Naturwissenschaftliche Abhandlungen, 3:41-92.

Rosso, A. 2002. Terataulopocella borealis gen. et sp. nov., a deep-water Pliocene Lekythoporid (Briozoa) from the Mediterranean Area. Memorie di Scienze Geologiche, 54:65-72.

Ruggieri, G. 1975. Revisione della ostracofauna marina quaternaria di Imola (Bologna). Revista Española de Micropaleontologia, 3:419-446.

Ruggieri, G. 1992. Considerazioni tassonomiche su ostracodi neogenici e pleistocenici risultate dalla revisione di vecchi lavori dello scrivente. Bollettino della Società Paleontologica Italiana, 31:175-188.

Sars, G.O. 1866. Oversigt af Norges marine Ostracoder. Forhandlinger i Videnskabs - Selskabet i Christiania, 7:1-30.
Schornikov, E.I. 1988. The pathways of morphological evolution of Bythocytheridae, p. 951-965. In Hanai, T., Ikeya, N., and Ishizaki, K. (eds.), Evolutionary Biology of Ostracoda - Its Fundamentals and Applications. Developments in Palaeontology and Stratigraphy, 11. Elsevier and Kodansha, Tokyo.

Schornikov, E.I. 1990. Evolution and classification of Bythocytheridae. Courier Forschungsinstitut Senckenberg, 123:291-302.

Schudack, U. and Schudack, M.E. 2000. Ostracods from the Upper Jurassic (Oxfordian-Tithonian) of Southern Germany. Journal of Micropaleontology, 19:97-112.

Sciuto, F. 2003. Dati preliminari sulla ostracofauna pliocenica di Capo Milazzo (Sicilia NE). Bollettino della Società Paleontologica Italiana, 42:179-184.

Sciuto, F. 2005. Ostracodi batiali pleistocenici di Capo Milazzo (Sicilia NE) ed implicazioni paleoambientali. Rendiconti della Società Paleontologica Italiana, 2:219-227.

Sciuto, F. 2009. Bythocythere mylaensis n. sp. (Crustacea, Ostracoda) from Early Pleistocene of Capo Milazzo (NE Sicily). Bollettino della Società Paleontologica Italiana, 48:183-188.

Sciuto, F. 2012. Bythocythere solisdeus n. sp. and Cytheropteron eleonorae n. sp. (Crustacea, Ostracoda) from the Early Pleistocene Bathyal Sediments of Cape Milazzo (NE, Sicily). Geosciences, 2:147-156.

Sciuto, F. 2014. Ostracods of the Upper Pliocene - Pleistocene Punta Mazza succession (NE Sicily) with special focus on the family Trachyleberididae Sylvester-Bradley, 1948 and description of a new species. Carnets de Géologie [Notebooks on Geology], 14(1):1-13.

Seguenza, G. 1880. Le formazioni terziarie nella provincia di Reggio Calabria. Reale Accademia dei Lincei, Memorie della Classe di scienze fisiche, matematiche e naturali, serie 3(6):1-416.

Sissingh, W. 1971. Tricostate Trachileberidinae (Ostracoda) from Neogene-Recent deposits of Europe. Koninklijke Nederlandse Akademie van Wetenschappen ser. B, 74:195-205.

Slipper, I.J. 1997. Turonian (Late Cretaceous) Ostracoda from Dover, South East England. Unpublished Thesis. The University of Greenwich. gala.gre.ac.uk/ 6302/1/lan_Jeffrey_Slipper_1997.pdf

Terquem, O. 1878. Les foraminifères et les entomostracès-ostracodes du Pliocène Supérieur de l'lle de Rhodes. Deuxième Section (ostracodes). Mémoires de la Société Géologique de France, 3:81135.

Violanti, D. 1988. I foraminiferi plio-pleistocenici di Capo Milazzo. Bollettino del Museo Regionale di Scienze Naturali Torino, 6:359-392.

Weaver, P.P.E. 1982. Ostracoda from the British Lower Chalk and Plenus Marls. Monograph of the Palaeontological Society, London, Publication 562, Part of Volume 135 for 1981. 
Whatley, R. and Boomer, I. 1995. Upper Oligocene to Pleistocene ostracoda from guyots in the western pacific. Holes $871 \mathrm{~A}$ and $873 \mathrm{~B}$. Proceedings of the Ocean Drilling Program, Scientific Results, 144:8796.
Wilkinson, I.P. 1988. Ostracoda across the Albian/Cenomanian (Cretaceous) boundary in Cambridgeshire and Western Suffolk, Eastern England, p. 12291244. In Ikeya, N., Ishizaki, K., and Hanai, T. (eds.), Evolutionary biology of Ostracoda. Its fundamentals and applications. Developments in Palaeontology and Stratigraphy, 11. Elsevier and Kodansha, Tokio. 